\title{
Olga Viktorovna Loseva (22.02.1971-18.03.2017)
}

Olga Viktorovna Loseva deceased in Greece on March 18, 2017 after a severe and protracted illness. She was forty-six years old. Loseva was an outstanding researcher of the manuscript heritage of the Old Rus and a renowned specialist in Greek and Cypriote history and art. For a long time she was active as research associate, then as the head of a department of hagiography at the Ecclesiastical Scholarly Center "The Orthodox Encyclopedia". After moving to Greece with her husband she continued to co-operate intensively with the Encyclopedia as contributor and freelance editor.

Olga Loseva was born in Moscow, her father Viktor Ivanovich Losev was a high-reputed researcher and publisher of the manuscript heritage of the famous Russian writer Mikhail Bulgakov. In 1995 she graduated summa cum laude from the faculty of history of Moscow State Lomonosov University. Her scholarly interests always revolved around the study of manuscripts. For a long time she worked as researcher for the Manuscript department of the Russian State Library. In 1999 she defended Ph.D. thesis entitled "Menologia of Old Russian Gospels of the Eleventh-Twelfth Centuries". In 2001 Loseva published a book "Russian Menologia of the Eleventh-Fourteenth Centuries", which became a very important contribution to the study of the Old Russian manuscript tradition. This study had been result of ten years work: it involved the entire corpus of surviving manuscript sources that contain menologia (mesiatseslovy, short ecclesiastical calendars) and included analysis of the influence exercised by Greek prototypes on the Russian menologia. In 2003 the book was awarded Junior Prize of Metropolitan Makarij (Bulgakov) of Moscow and Kolomna foundation.

For over 15 years, starting in 2001, Olga Loseva worked for the ESC "The Orthodox Encyclopedia", where, due to her broad scholarly interests, excellent erudition and free command of the Modern Greek, she was responsible for several subject matters: Byzantine and Modern Greek hagiography, history of Greece and Cyprus in modern times, history of the Orthodox Church of Greece. In all these realms she was active both as highly qualified editor and as prolific contributor. In total, she authored more than 1000 articles for the Orthodox Encyclopedia.

The work for the Encyclopedia went hand-in-hand with research activities. Loseva participated in scholarly conferences on Byzantine and Old Russian art and history, published papers in scholarly periodicals (about 40 entries). In 2009 she published her second monograph "Lives of Russian Saints in Old Russian Synaxaria (Prologi) of the Twelfth to the First Third of the Fifteenth 
Century", which she dedicated to the memory of her teacher Lidija Petrovna Zhukovskaja, a prominent Slavist and linguist. Just as her first book, this work is remarkable for an extraordinary scope of the sources involved, which enabled the author to reconstruct a full-scale picture of emergence and development of the Old Russian hagiography.

Church history and hagiography for Loseva were not just branches of scholarship, but also an important part of her spiritual life as deeply religious Orthodox Christian.

The premature passing away of Olga Loseva is an irreplaceable loss for the Russian scholarship as well as a most heavy blow to her relatives and friends. Everyone who knew Olga remember her as a person of bright and strong character, infinitely dedicated to her vocation, which literally made up her life. At the same time, she always remained a sincere and responsive friend, ready to help, to join in joy or sorrow. She gladly shared her vast experience with younger colleagues, never denied anyone assistance. While fighting the grave illness Olga Loseva worked on scholarly papers to the last days of her life.

Loseva's remarkable investigation approach combined methodical selection of Old Russian sources and deep analysis of them with constant recursion to the Greek prototypes. Her works constitute a major contribution to the study of Old Russian and Byzantine hagiography.

\section{O. Afinogenova \\ D. Afinogenov}

\section{Main Works}

\section{Monographs}

Русские месяцесловы ХI-XIV вв., М., 2001 [Russian menologia of the 11th-14th centuries, Moscow, 2001]

Жития русских святых в составе древнерусских Прологов XII - первой трети XV в., M., 2009 [Lives of Russian saints in Old Russian synaxaria (Prologi) of the 12th to the first third of the 15th century, Moscow, 2009]

\section{Papers}

Месяцеслов Архангельского Евангелия 1092 г. [Menologion of the Arkhangelsk Gospel of 1092], Архангельскому Евангелию 1092 года - 900 лет, М. (1995), сс. 46-54 [900 years of the Arkhangelsk Gospel, Moscow (1995), pp. 46-54]

О родстве месяцесловов Остромирова Евангелия и Охридского Апостола [On the affinity between menologia of the Ostromir Gospel and Ochrid Apostle], Записки 
OР Ргь, М. (1995), вып. 50, сc. 324-329 [Memoirs of the MD of RSL, Moscow (1995), 50, pp. 324-329]

Одна из загадок месяцеслова Остроимирова Евангелия [One of the riddles of the Ostromir Gospel menologion], Румянцевские чтения, М. (1996), ч. 2, сс. 56-6o [Rumiantsev readings, Moscow (1996), part 2, pp. 56-6o]

Месяцеслов и именослов в Древней Руси [Menologion and onomatologion in Old Rus], Румянцевские чтения: Материалы научно-практической конференции, M. (1996), ч. 2, cc. 63-71 [Rumiantsev readings. Proceedings of the scholarly-practical conference, Moscow (1996), part 2, pp. 63-71]

О землетрясениях в греческих и древнерусских месяцесловах и об особенностях Холмского Евангелия ХІІІ в. [On earthquakes in Greek and Old Russian menologia and on peculiarities of the 13th century Kholm Gospel], Записки ор Ргь,М. (2000), вып. 51, сc. 339-349 [Memoirs of the MD of RSL, Moscow (2000), 51, pp. 339-349]

Периодизация древнерусских месяцесловов XI-XIV в. [Chronological distribution of Old Russian menologia of the 11th-14th c.], Древняя Русь (2001'), 4, сс. 15-36 [Drevniaja Rus' (2001' $)$, 4, pp. 15-36]

“Латиняне” в проложном сказании 9 мая [“Latins" in the Prolog entry for May, 9], Византия и Запад: 950-летие схизмы христианской Церкви, 8оо- летие захвата Константинополя крестоносцами, М. (2004), cc.112-116 [Byzantium and the West: 950 years of the Schism of the Christian Church, 800 years of the sack of Constantinople by the Crusaders, Moscow (2004), pp. 112-116]

Особенности состава древнерусского Пролога 1313 г. (гим Син. 239) [Peculiarities of composition of the Old Russian Prolog of 1313 (GIm Sin. 239)], Древняя Русь $\left(2004^{1}\right), 2$ (16), cc. 96-10o [Drevniaja Rus' (2004 $\left.{ }^{1}\right), 2$ (16), pp. 96-10o]

Молитва над болящим в составе требника Рнь, Q.п.I. 24, XIV в. [Prayer over the sick in the Ritual RNB, Q.п.I. 24 of the 14th c.], KANISKION: Юбилейный сборник в честь 6о-летия И.С. Чичурова. Ред. М.В. Грацианский, П.В. Кузенков, М. (2006), сс. 280303 [KANISKION: Festschrift for the 6oth birthday of I.S. Čičurov. Ed. M.V. Gratsiansky, P.V. Kouzenkov, Moscow (2006), pp. 280-303]

“Слово от Жития святого Феодосия" в составе древнерусского Пролога [“Sermon from the Life of St Feodosij” in the Old Russian Prolog], Проблемы источниковедения, M. (2006), вып. 1 (2), сс. 38-40 [ Problems of source criticism, Moscow (2006), 1 (2), pp. 38-40]

География Византийской империи глазами переводчика древнерусского Пролога [Geography of the Byzantine Empire in the eyes of the translator of the Old Russian Prolog], Восточная Европа в древности и средневековье, М. (2006), сс. 114-117 [Eastern Europe in Antiquity and Middle Ages, Moscow (2006), pp. 114-117]

Жития русских святых в составе первой редакции древнерусского Пролога [Lives of Russian Saints in the first redaction of the Old Russian Prolog], Религии мира. Истории и современность: 2005, М. (2007), сc. 92-94 [Religions of the World: History and Modernity: 2005, Moscow, (2007), pp. 92-94] 
Какой редакцией пролога пользовался Кирилл Туровский? [Which redaction of Prolog was used by Kirill of Turov?], История: Дар и долг: Юбилейный сборник в честь А.В. Назаренко. Ред. Н.Н. Лисовой, М.; спб., (2010), cc. 137-151 [History: Gift and Duty. Festschrift in honor of A.V. Nazarenko. Ed. N.N. Lisovoy, Moscow, St. Petersburg (2010), pp. 137-151]

Сказания об иконе Божией Матери Портаитиссы: предварительные наблюдения [Narrations on the icon of Theotokos Portaitissa: preliminary observations], THEOdoulos: Сборник статей памяти проф. И.С. Чичурова. Ред.: П.В. Кузенков, A.A. Войтенко, М.В. Грацианский, М. (2012), cc. 183-20 [тнЕоDoulos: Collection of articles in memory of Prof. I.S. Čičurov. Ed. P.V. Kouzenkov, A.A, Vojtenko, M.V. Gratsianskiy, Moscow (2012), pp. 183-202]

Olga Loseva has authored more than 1000 articles for the Orthodox Encyclopedia dedicated to Byzantine, Post-Byzantine, and Modern Greek saints, monasteries, prominent ecclesiastical figures as well as bishoprics and metropolitan dioceses of Helladic, Alexandrian and Constantinopolitan Orthodox Churches.

\section{Selected Recent Publications}

Кипрская Православная Церковь, Православная энциклопедия, М. (2014), 34 (Разделы: Распространение христианства, сс. 9-21; кпц в период британского правления, сс. 34-48; кпц в независимой республике Кипр, сс. 48-58) [The Orthodox Church of Cyprus, The Orthodox Encyclopedia, Moscow (2014), 34 (Sections: Expansion of Christianity, pp. 9-21; occ in the period of British rule, pp. 34-48; occ in the independent Republic of Cyprus, pp. 48-58)]

Критская Православная Церковь [The Orthodox Church of Crete], Православная энциклопедия, М. (2015), 39, cc. 22-29 [The Orthodox Encyclopedia, Moscow (2015), 39, pp. 22-29].

Мария Магдалина, Православная энциклопедия, М. (2016), 43 (Разделы: Мария Магдалина в византийской и новогреческой агиографической традиции; Мощи Марии Магдалины на православном Востоке, сс. 569-572). [Mary Magdalene, The Orthodox Encyclopedia, Moscow (2016), 43. (Sections: Mary Magdalene in the Byzantine and Modern Greek hagiographic tradition; The relics of Mary Magdalene in the Orthodox East, pp. 569-572)]. 


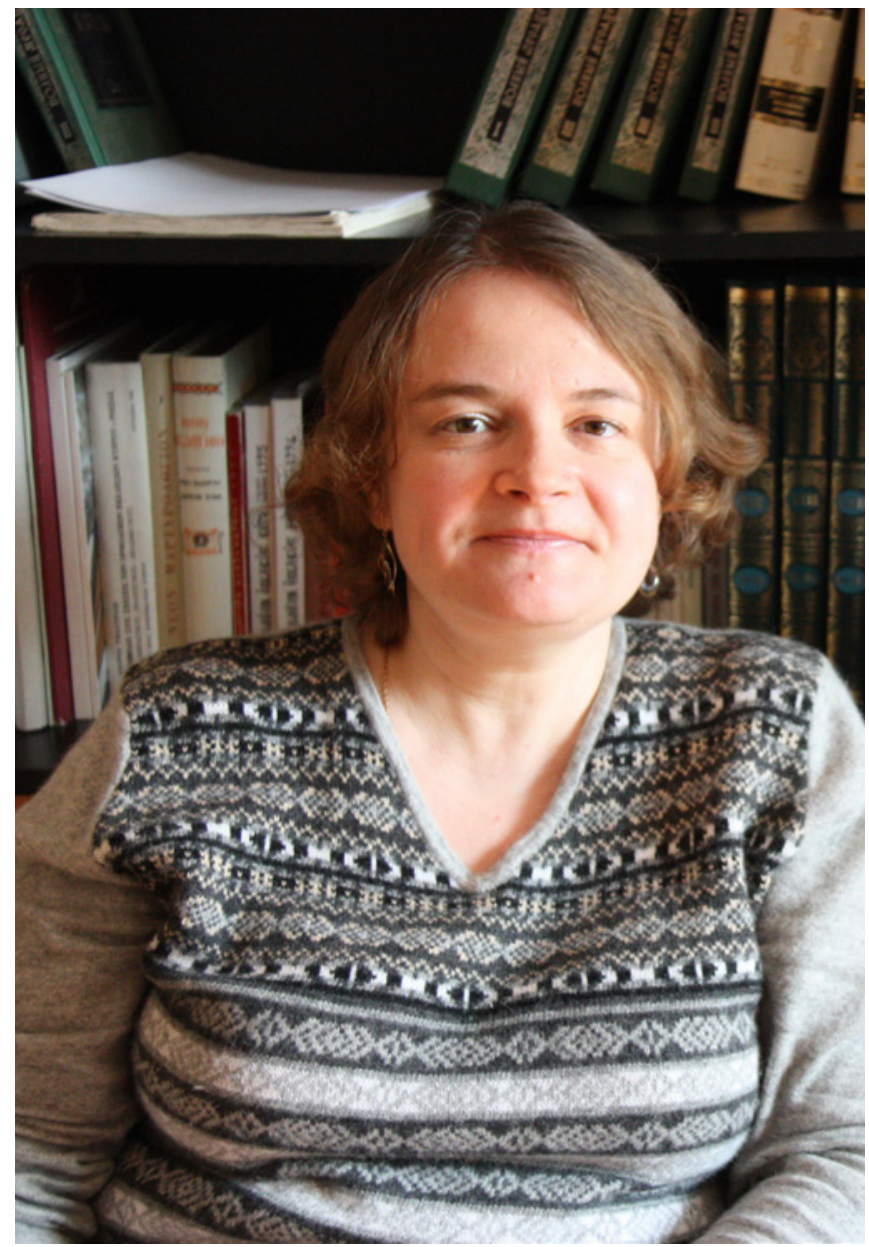

Olga Viktorovna Loseva 